\title{
PENENTUAN SIFAT TERMOFISIK TEMU LAWAK DAN TEMU PUTIH
}

\section{Thermal Properties Of Java Turmeric and Zedoary}

Lamhot P. Manalu ${ }^{1)}$, Amos ${ }^{2)}$, Wahyu dan Purwanto ${ }^{1)}$

Pusat Teknologi Agroindustri ${ }^{1)}$ dan Pusat Audit Teknologi ${ }^{2)}$ BPPT

Gd. 2 Lt. 17 dan Lt. 12 Jl. Thamrin 8 Jakarta 10340

e-mail: Ipmanalu@yahoo.com dan amoslukas2010@gmail.com

Diterima : 27 Maret 2012, Revisi akhir: 22 Mei 2012

\begin{abstract}
ABSTRAK
Dalam merancang suatu sistem proses dan peralatan pengolahan hasil pertanian diperlukan pengetahuan tentang sifat-sifat panas suatu bahan diantaranya panas jenis, konduktivitas, dan difusivitas panas. Nilai-nilai tersebut untuk produk pertanian lokal sangat jarang ditemukan, sehingga dalam aplikasinya sering digunakan data sifat panas dari literatur luar yang belum tentu sesuai dan tepat dengan produk dalam negeri. Hal ini dapat menyebabkan terjadinya bias dalam perhitungan dan perancangan. Studi ini bertujuan untuk menentukan sifat-sifat/properti panas dari tanaman obat temu lawak dan temu putih. Hasil studi mendapatkan bahwa panas jenis temu lawak dan temu putih adalah masing-masing $2.835 \mathrm{~kJ} / \mathrm{kg}^{\circ} \mathrm{C}$ dan $2.863 \mathrm{~kJ} / \mathrm{kg}^{\circ} \mathrm{C}$, konduktivitas panas masing-masing adalah $0.2797 \mathrm{~W} / \mathrm{m}^{\circ} \mathrm{C}$ dan $0.1359 \mathrm{~W} / \mathrm{m}^{\circ} \mathrm{C}$, sedangkan nilai difusivitas panasnya masing-masing adalah $9.34 \times 10^{-8} \mathrm{~m}^{2} /$ detik dan $1.00 \times 10^{-7} \mathrm{~m}^{2} /$ detik.
\end{abstract}

\section{Kata Kunci : Temu lawak, temu putih, panas jenis, konduktivitas, difusivitas panas}

\section{ABSTRACT}

The most important limitation in process design for agricultural products is the lack of information on their thermal properties. Although a lot of experimental data can be found, the variety of products and the differences in measurement method make limitation on the value of the available data, especially for Indonesia's products. These data are required to get information about temperature change when product is processed like heating or cooling. It is worth due to optimizing the efficiency of energy. The objective of this study was to determine thermal diffusivity and conductivity of java turmeric and zedoary herbs. The values were determined numerically with indirect methods. The result showed that specific heat of java turmeric and zedoary were $2.835 \mathrm{~kJ} / \mathrm{kg}^{\circ} \mathrm{C}$ and $2.863 \mathrm{~kJ} / \mathrm{kg}^{\circ} \mathrm{C}$, thermal conductivity were $0.2797 \mathrm{~W} / \mathrm{m}^{\circ} \mathrm{C}$ and $0.1359 \mathrm{~W} / \mathrm{m}^{\circ} \mathrm{C}$, respectively, while thermal diffusivity were $9.34 \times 10^{-8} \mathrm{~m}^{2} / \mathrm{s}$ and $1.00 \times 10^{-7} \mathrm{~m}^{2} / \mathrm{s}$, respectively. Keywords: Java turmeric, zedoary, specific heat, thermal conductivity, thermal
diffusivity

\section{PENDAHULUAN}

Produk pertanian termasuk tanaman obat merupakan produk yang mudah rusak sehingga diperlukan cara-cara penanganan pascapanen yang lebih baik untuk dapat memperpanjang umur simpan. Perlakuan pendinginan adalah cara yang biasa dilakukan untuk memperpanjang umur simpan sekaligus mempertahankan kualitas produk dengan syarat suhu, waktu dan parameter pendinginan lainnya sesuai dengan karakteristik produk yang didinginkan (Rizvi, 2005). Demikian juga dengan perlakuan panas baik menggunakan air panas, uap panas maupun kombinasi keduanya merupakan perlakuan pendahuluan dalam penanganan segar sayuran dan buahbuahan untuk menekan pertumbuhan mikroorganisme seperti jamur (Mayor and Sereno, 2004). 
Untuk merancang sistem pendinginan dan pemanasan yang baik dan tepat untuk komoditas pertanian, perlu diketahui karakteristik atau sifat termofisik (thermal properties) masing-masing produk. Hal ini dapat dipahami mengingat pendinginan dan perlakuan panas berkaitan erat dengan dengan proses pindah panas. Sifat termofisik akan menentukan karakteristik perubahan suhu produk sehingga dapat ditentukan kebutuhan energi dan waktu perlakuan secara tepat (Weidenfellera, 2004). Nilai difusivitas panas bahan merupakan salah satu sifat panas yang dibutuhkan untuk menduga laju perubahan suhu bahan sehingga dapat ditentukan waktu optimum yang dibutuhkan dalam proses pengolahan, pengeringan atau pendinginan (Singh and Goswami, 2000). Dengan mengetahui waktu optimum tersebut, selain dapat menghindarkan terjadinya kerusakan bahan juga dapat menghemat penggunaan energi.

Temu putih (Curcuma zedoaria Berg.) merupakan tanaman semak dengan tinggi sekitar $2 \mathrm{~m}$. Bagian tanaman yang digunakan sebagai obat adalah umbi akar yang diiris dan dikeringkan. Rimpang temu putih mengandung zat warna kuning yang disebut kurkuminoid (diarilheptanoid) dan senyawa kimia lain, seperti: minyak atsiri, zingiberen, sineol, polisakarida, dan golongan lain. (BPOM, 2007). Komponen yang dominan di dalam temu putih adalah minyak atsiri, beberapa penelitian melaporkan bahan aktif temu putih bersifat anti kanker dan anti oksidan (Seo et al., 2005; Mau et al., 2003).

Temu lawak (Curcuma xanthorrhiza Roxb.) merupakan tanaman asli Indonesia yang tumbuh liar di hutan-hutan di dataran rendah hingga $1500 \mathrm{~m}$ di atas permukaan laut (Syukur, 2003). Rimpang temu lawak segar terdiri atas minyak atsiri, lemak, zat warna, protein, resin, selulosa, pati, mineral dan air. Temu lawak berkhasiat sebagai anti-bakteria, anti-kanker, anti-tumor dan anti-radang. Selain itu rimpang temu lawak mengandung anti-oksidan dan hypocolesteromic (Hwang et al., 2000; Choi et al., 2005).

Penelitian ini bertujuan untuk menentukan nilai difusivitas, konduktivitas panas $(k)$, massa jenis $(\rho)$, dan panas jenis
(Cp) tanaman obat temu lawak dan temu putih.

\section{METODOLOGI PENELITIAN}

\section{Bahan}

Bahan yang digunakan adalah umbi akar temu lawak dan temu putih.

Alat

Alat-alat yang digunakan adalah thermal conductivity meter (Kemtherm QTMD3), lemari pendingin (Ebara 3848), hybrid recorder (HR-2500E), termokopel CC, drying oven (Ikeda SS-204D), timbangan digital (AND EK-1200A), kalorimeter, termometer, jangka sorong, stopwatch dan gelas ukur.

Metode yang digunakan dalam menentukan sifat-sifat panas produk yang mencakup panas jenis, konduktivitas panas dan difusivitas panas adalah sebagai berikut.

\section{Penentuan Panas Jenis}

Panas jenis didefinisikan sebagai jumlah energi yang dibutuhkan oleh satu satuan berat $(m)$ bahan untuk menaikkan suhunya sebesar satu derajat (Cengel and Boles, 2002). Besaran ini dipakai untuk menduga jumlah energi $(Q)$ yang diperlukan bila suhu bahan berubah satu satuan $(\Delta T)$. Panas jenis temu lawak dan temu putih ditentukan dengan menggunakan kalorimeter yang dihitung dengan menggunakan persamaan berikut,

$\mathrm{Cp}=\frac{\mathrm{Q} / \mathrm{T}}{\mathrm{m}}$

Untuk menghitung panas jenis bahan pada kondisi di atas titik beku digunakan suatu rumus yang dikenal sebagai persamaan Siebel (Rao et al., 2005; Wirakartakusumah et al., 1992) sebagai berikut :

$C p=4,1868(0.008 M+0.20)$

dimana $M$ adalah persentase kadar air (basis basah). 
Metode yang diajukan Charm dalam menghitung panas jenis turut mempertimbangkan kandungan lemak bahan (Heldman and Singh, 1981). Metode ini cukup baik terutama bagi bahan-bahan yang kandungan lemaknya cukup tinggi.

$C p=4,1868\left(0,5 X_{f}+0,33 X_{s}+X_{m}\right)$

dimana $X_{f}$ adalah fraksi lemak, $X_{s}$ adalah fraksi padatan dan $X_{m}$ adalah fraksi air dalam bahan.

Selain dua metode di atas, panas jenis dapat ditentukan dengan metode campuran (method of mixtures). Metode ini banyak dipakai karena caranya sederhana yaitu dengan memasukkan bahan yang sudah diketahui masanya $\left(W_{s}\right)$ ke dalam kalorimeter berisi air yang sudah diketahui berat $\left(W_{w}\right)$ dan panas jenisnya $\left(C_{w}\right)$. Pengukuran dengan metode campuran didasarkan pada hukum keseimbangan panas dalam kalorimeter yang secara matematis ditulis sebagai berikut (Mohsenin, 1980):

$$
\begin{aligned}
C_{s}{ }^{*} W_{s}\left(T_{\mathrm{a}}-T_{\mathrm{e}}\right)= & C_{\mathrm{w}}{ }^{*} W_{\mathrm{w}}\left(T_{\mathrm{e}}-T_{\mathrm{o}}\right)+ \\
& C_{c}{ }^{*} W_{c}\left(T_{\mathrm{e}}-T_{\mathrm{o}}\right)
\end{aligned}
$$

Panas jenis dan massa kalorimeter dianggap konstan sehingga perkaliannya merupakan kapasitas panas kalorimeter. Persamaan di atas dapat ditulis sebagai berikut (Mohsenin, 1980):

$$
C_{s}=\frac{C_{w} W_{w}\left(T_{e}-T_{o}\right)+H c\left(T_{e}-T_{o}\right)}{W_{s}\left(T_{a}-T_{e}\right)}
$$

Kapasitas panas kalorimeter $\left(H_{C}\right)$ dapat ditentukan dengan mencampur sejumlah air yang berbeda suhu awalnya dalam kalorimeter hingga dicapai suhu keseimbangan. Persamaan berikut digunakan untuk menetukan kapasitas panas untuk kondisi tersebut (Mohsenin, 1980):

$$
\mathrm{H}_{\mathrm{c}}=\frac{\mathrm{C}_{\mathrm{h}} \mathrm{W}_{\mathrm{h}}\left(\mathrm{T}_{\mathrm{a}}-\mathrm{T}_{\mathrm{e}}\right)+\mathrm{Cc} \mathrm{W}_{\mathrm{c}}\left(\mathrm{T}_{\mathrm{e}}-\mathrm{T}_{\mathrm{o}}\right)}{\left(\mathrm{T}_{\mathrm{e}}-\mathrm{T}_{\mathrm{o}}\right)}
$$

dimana:

$H_{c}=$ kapasitas panas kalorimeter, $\mathrm{kJ} /{ }^{\circ} \mathrm{C}$

$W_{h}=$ massa air panas, $\mathrm{kg}$

$W_{c}=$ massa air dingin, $\mathrm{kg}$

$T_{a}=$ suhu awal air panas, ${ }^{\circ} \mathrm{C}$
$T_{e}=$ suhu keseimbangan, ${ }^{\circ} \mathrm{C}$

$T_{o}^{e}=$ suhu awal air dingin, ${ }^{\circ} \mathrm{C}$

$C_{h}=$ panas jenis bahan, $\mathrm{kJ} / \mathrm{kg}^{\circ} \mathrm{C}$

$W_{s}=$ massa bahan, $\mathrm{kg}$

$C_{c}=$ panas jenis kalorimeter, $\mathrm{kJ} / \mathrm{kg}^{\circ} \mathrm{C}$

\section{Penentuan Konduktivitas Panas}

Konduktivitas panas adalah sifat termal suatu benda untuk merambatkan panas dalam suatu unit waktu melalui luas penampang tertentu yang diakibatkan oleh adanya perbedaan suhu. Untuk bahan hayati, besarnya nilai konduktivitas panas $(k)$ banyak dipengaruhi oleh beberapa faktor seperti struktur sel/fisik, komposisi kimia bahan, dan kandungan air. Variasi nilai konduktivitas panas bahan hayati lebih besar dibandingkan bahan non-hayati (Jangam and Mujumdar, 2010).

Dalam percobaan ini konduktivitas panas produk diukur langsung dengan menggunakan alat conductivity meter, sedangkan secara tidak langsung konduktivitas panasnya dihitung dengan persamaan Sweat (Phomkong et al., 2006) sebagai berikut :

$k=0,148+0,00493 M$

dimana $M$ adalah kadar air produk ( $\% \mathrm{bb})$.

\section{Penentuan Difusivitas Panas}

Difusivitas panas dapat diartikan sebagai laju pada saat panas terdifusi keluar dari bahan. Distribusi suhu pada suatu bahan dalam kondisi tidak mantap telah dirumuskan oleh persamaan umum Fourier (Yagua and Moreira, 2011) sebagai berikut :

$$
\partial T / \partial \quad t=\alpha \quad \nabla^{2} T
$$

dimana $T$ adalah suhu pada titik tertentu (pada koordinat $x, y$ dan $z$ ), $t$ adalah waktu dan adalah koefisien difusivitas panas.

Dengan mengasumsikan umbi temu lawak dan temu putih berbentuk silinder dan perpindahan panas merata ke arah radial, suhu awal di setiap titik dianggap seragam, kadar air tetap dan tidak terjadi penyusutan, persamaan (8) dapat ditulis sebagai berikut (Jangam and Mujumdar, 2010) : 
$\frac{T}{t}=\alpha\left(\frac{T^{2}}{\text { Persamatan }}+\frac{1}{(9)}\right)$

${ }^{t}$ Persamaan (9) dir atas didiskritisasi memakai metode numerik beda hingga sehingga diperoleh :

$$
\begin{aligned}
& T_{i}^{j+t}-T_{i}^{j}=s\left[\left(T_{i+1}^{j}-2 T_{i}^{j}+T_{i-1}^{j}\right)\right. \\
& +\frac{1}{i}\left(T^{j}{ }_{i+1}\right. \\
& \left.-T_{i-1}^{j}\right]
\end{aligned}
$$

Selanjutnya nilai $S$ dihitung dengan metode kuadrat terkecil (least square method) dan nilai difusivitas panas $(\alpha)$ dihitung dengan persamaan (11) berikut.

$s=\frac{t}{(r r)^{2}}<0,5$

Dalam hubungannya dengan sifat termofisik bahan lainnya, nilai difusivitas panas berbanding lurus dengan konduktivitas panas $(k)$ dan berbanding terbalik dengan panas jenis $\left(C_{p}\right)$ dan kerapatan bahan () tersebut.

Hubungan yang digambarkan pada persamaan (12) dapat dipakai untuk menentukan difusivitas panas yang dikenal sebagai metode tidak langsung.

$$
a=\frac{k}{P_{\text {enen }}}
$$

Pénentuan difusifitas panas secara langsung dengan metoda numerik dilakukan dengan menggunakan data distribusi perubahan suhu produk selama pendinginan. Data perubahan suhu bahan diambil dari tiga titik pengukuran. Titik pertama merupakan titik pusat sedangkan titik kedua dan ketiga diukur berjarak $r$ dan $2^{*} \Delta r$ ke arah radial. Pengukuran dihentikan bila suhu di setiap titik pengamatan sudah relatif seragam.

\section{HASIL DAN PEMBAHASAN}

\section{Penentuan panas jenis bahan}

Berdasarkan data pengukuran dan hasil perhitungan didapatkan massa jenis $(\rho)$ temu lawak dan temu putih masing-masing adalah $1057 \mathrm{~kg} / \mathrm{m}^{3}$ dan $1234 \mathrm{~kg} / \mathrm{m}^{3}$. Dari hasil ini terlihat bahwa massa jenis temu putih cenderung lebih besar daripada temu lawak.

Grafik perubahan suhu untuk menentukan suhu keseimbangan hasil campuran antara produk, air dan kalorimeter untuk temu lawak dapat dilihat pada Gambar 1 dan 2.

\section{Grafik perubahan suhu temulawak (1)}

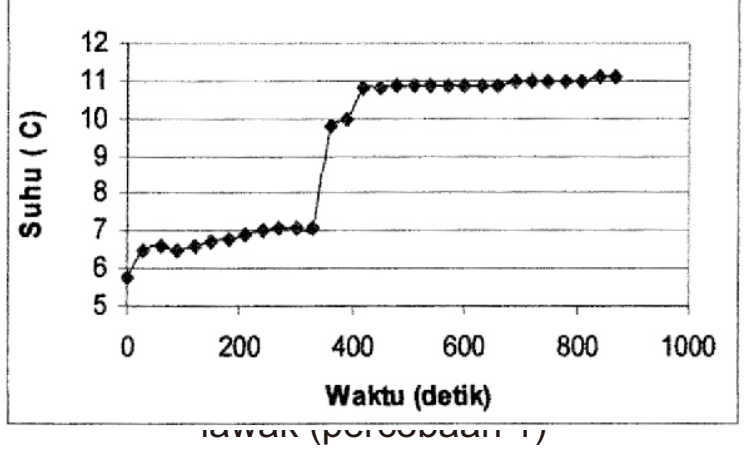

\section{Grafik perubahan suhu temulawak (2)}

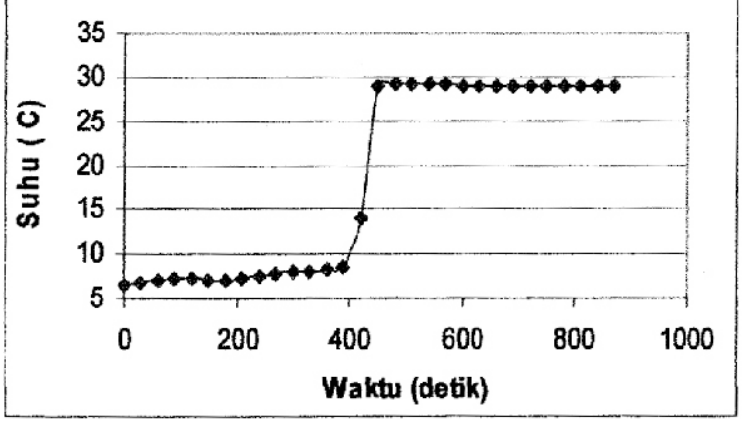

Grafik perubahan suhu untuk menentukan suhu keseimbangan hasil campuran antara produk, air dan kalorimeter untuk temu putih dapat dilihat pada Gambar 3 dan 4.

Panas jenis produk dihitung berdasarkan data pengukuran perubahan suhu dan menggunakan persamaan keseimbangan energi antara produk, air dan kalorimeter (Tabel 1 dan 2). Panas jenis temu lawak adalah $2,835 \mathrm{~kJ} / \mathrm{kg}^{\circ} \mathrm{C}$ pada kadar air $79 \%$ 
(bb), dan panas jenis temu putih adalah $2.863 \mathrm{~kJ} / \mathrm{kg}^{\circ} \mathrm{C}$ pada kadar air $87 \%(\mathrm{bb})$.
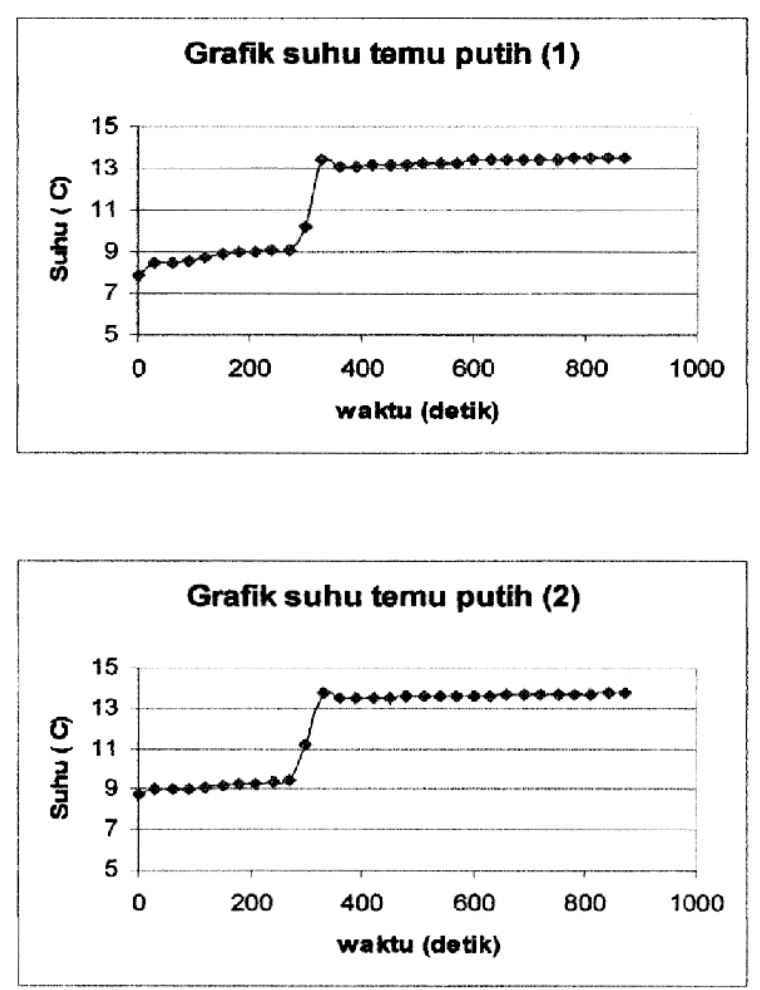

Tabel 1. Penentuan Cp temulawak

\begin{tabular}{|c|c|c|c|}
\hline & Satuan & TL-1 & TL-2 \\
\hline $\mathrm{Te}$ & $C$ & 9.8 & 11.9 \\
\hline Tw & C & 7.1 & 9.3 \\
\hline $\mathrm{Mw}$ & g & 200 & 200.03 \\
\hline Cpw & $\mathrm{J} / \mathrm{gC}$ & 4.2 & 4.195 \\
\hline $\mathrm{Mp}$ & $\mathrm{g}$ & 200 & 200.03 \\
\hline $\mathrm{Tp}$ & C & 28 & 29 \\
\hline Cppe & $\begin{array}{l}\mathrm{J} / \mathrm{gC} \\
\text { engent } \\
\text { lwak (k }\end{array}$ & Gép & 2.922 \\
\hline
\end{tabular}

\begin{tabular}{|c|c|c|c|c|}
\hline & Satuan & TP-1 & TP-2 & TP-3 \\
\hline $\mathrm{Te}$ & $C$ & 12 & 12 & 11 \\
\hline Tw & C & 9.1 & 9.5 & 8.7 \\
\hline Mw & $g$ & 200 & 200 & 200 \\
\hline Cpw & $\mathrm{J} / \mathrm{gC}$ & 4.195 & 4.195 & 4.198 \\
\hline $\mathrm{Mp}$ & $g$ & 50 & 50.01 & 50.01 \\
\hline $\mathrm{Tp}$ & C & 28.8 & 28.8 & 29.04 \\
\hline Cpp & $\mathrm{J} / \mathrm{gC}$ & 3.303 & 2.846 & 2.440 \\
\hline
\end{tabular}

dihitung menggunakan persamaan Siebel (persamaan 2). Menurut Siebel, nilai $C_{p}$ bahan sangat dipengaruhi oleh kadar airnya. Berdasarkan Siebel nilai panas jenis temulawak adalah $3.760 \mathrm{~kJ} / \mathrm{kg}^{\circ} \mathrm{C}$ dan panas jenis temu putih adalah $4.056 \mathrm{~kJ} / \mathrm{kg}^{\circ} \mathrm{C}$.

Panas jenis produk semakin tinggi bila kadar airnya semakin tinggi. Hal ini menunjukkan adanya korelasi positif antara panas jenis dan kadar air karena panas jenis air lebih tinggi dari padatannya. Dengan demikian dapat dimengerti bahwa metode Siebel cukup baik diterapkan untuk bahan yang mengandung kadar air tinggi.

\section{Penentuan konduktivitas panas bahan}

Pada Tabel 3 dan 4 dapat dilihat nilai pengukuran konduktivitas panas temu lawak dan temu putih yang diperoleh dengan menggunakan peralatan thermal conductivity meter. Konduktivitas panas rata-rata temu lawak dan temu putih masingmasing adalah 0.2797 dan $0.3551 \mathrm{~W} / \mathrm{m}^{\circ} \mathrm{C}$ pada kisaran suhu $34-40^{\circ} \mathrm{C}$.

Tabel 3. Data untuk penentuan $\mathrm{k}$ temu lawak

\begin{tabular}{|c|c|c|c|}
\hline & Satuan & TL-1 & TL-2 \\
\hline T awal & $\mathrm{C}$ & 30 & 29 \\
\hline T akhir & $C$ & 50 & 49 \\
\hline T rata & C & 40 & 39 \\
\hline dT & $\mathrm{C}$ & 20 & 21 \\
\hline $\mathrm{k}$ & $\mathrm{W} / \mathrm{m} \mathrm{C}$ & 0.2713 & 0.2881 \\
\hline
\end{tabular}

\begin{tabular}{|c|c|c|c|}
\hline & Satuan & TL-1 & TL-2 \\
\hline T awal & C & 26 & 26 \\
\hline T akhir & C & 43 & 42 \\
\hline T rata & $\mathrm{C}$ & 35 & 34 \\
\hline dT & $\mathrm{C}$ & 17 & 16 \\
\hline $\mathrm{k}$ & $\mathrm{W} / \mathrm{m} \mathrm{C}$ & 0.3403 & 0.3698 \\
\hline \multicolumn{4}{|c|}{ 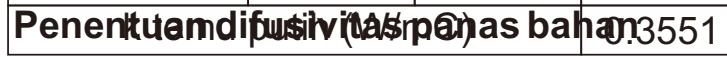 } \\
\hline
\end{tabular}

Penentuan difusivitas panas temu lawak 
dan temu putih dengan cara tidak langsung (persamaan 12). Dari hasil perhitungan (Tabel 5 dan 6) didapatkan nilai difusivitas panas temu lawak dan temu putih masingmasing adalah $9,34 \times 10^{-8}$ dan $1,00 \times 10^{-7}$ $\mathrm{m}^{2} /$ detik.

Nilai koefisien difusivitas panas dipengaruhi oleh suhu bahan atau suhu proses dimana nilainya semakin kecil bila suhu bahan semakin rendah. Akan tetapi untuk menyederhanakan perhitungan pada umumnya nilai difusivitas dianggap tetap.

Tabel 5. Penentuan difusivitas panas temu lawak

\begin{tabular}{|c|c|c|}
\hline Parameter & Satuan & Nilai \\
\hline Cp & $\mathrm{kJ} / \mathrm{kg}^{\circ} \mathrm{C}$ & 2.835 \\
\hline $\mathrm{k}$ & $\mathrm{W} / \mathrm{m}^{\circ} \mathrm{C}$ & 0.2797 \\
\hline $\begin{array}{l}\text { massa jenis } \\
\text { Tados } \\
\text { Difusivitas pa }\end{array}$ & 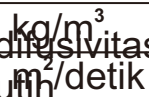 & $\begin{array}{l}\text { nastefin } \\
.34 \mathrm{E}-08\end{array}$ \\
\hline
\end{tabular}

\begin{tabular}{|l|l|r|}
\hline \multicolumn{1}{|c|}{ Parameter } & \multicolumn{1}{c|}{ Satuan } & \multicolumn{1}{c|}{ Nilai } \\
\hline $\mathrm{Cp}$ & $\mathrm{kJ} / \mathrm{kg}^{\circ} \mathrm{C}$ & 2.863 \\
\hline $\mathrm{k}$ & $\mathrm{W} / \mathrm{m}^{\circ} \mathrm{C}$ & 0.3551 \\
\hline massa jenis & $\mathrm{kg} / \mathrm{m}^{3}$ & 1234 \\
\hline KESULMAPitHsAd\&nas & $\mathrm{m}^{2} /$ detik & $1.00 \mathrm{E}-07$ \\
\hline
\end{tabular}

Sifat termofisik bahan sangat dipengaruhi oleh jenis dan kandungan bahan spesifik yang ada pada masing-masing jenis bahan. Penelitian ini telah berhasil menghitung sifat termofisik (thermal properties) temu putih dan temu lawak.

Nilai panas jenis $\left(C_{p}\right)$ temu putih dan temulawak, masing-masing adalah 2.863 $\mathrm{kJ} / \mathrm{kg}^{\circ} \mathrm{C}$, dan $2.835 \mathrm{~kJ} / \mathrm{kg}^{\circ} \mathrm{C}$. Nilai konduktivitas panas $(k)$ temu putih dan temulawak, masing-masing adalah 0.3551 $\mathrm{W} / \mathrm{m}^{\circ} \mathrm{C}$ dan $0.2797 \mathrm{~W} / \mathrm{m}^{\circ} \mathrm{C}$. Nilai difusivitas panas $(\alpha)$ temu putih dan temulawak, masing-masing adalah $1.00 \times 10^{-7} \mathrm{~m}^{2} /$ detik dan $9.34 \times 10^{-8} \mathrm{~m}^{2} /$ detik.

\section{DAFTAR PUSTAKA}

Badan Pengawas Obat dan Makanan. 2007. Temu Putih. BPOM, Jakarta.

Cengel, Y.A., and M.A. Boles. 2002. Thermodynamics: an Engineering Approach. Ed ke-4. Boston: Mc-Graw Hill.

Choi, M.A., Kim, S.H., Chung, W., Hwang, J.K., Park, K.K. 2005. Xanthorrhizol, a natural sesquiterpenoid from Curcuma xanthorrhiza, has an anti-metastatic potential in experimental mouse lung metastasis model. Biochemical and Biophysical Research Communications 326:210-217.

Heldman, D.R., and R.P. Singh. 1981. Food Process Engineering. The AVI Pub. Co. Inc., Westport, Connecticut.

Hwang, J.K., J.S. Shim and Y.R. Pyun. 2000. Antibacterial activity of xanthorrhizol from Curcuma xanthorrhiza against oral pathogens. Fitoterapia, 71:321-323.

Jangam, S.V., and A.S. Mujumdar. 2010. Basic concepts and definitions. Di dalam: Jangam SV, C.L. Law and A.S. Mujumdar, (Eds). Drying of Foods, Vegetables and Fruits. Singapore.

Mau, J.L., Lai, E.Y.C., Wang, N.P., Chen, C.C., Chang, C.H., Chya, C.C. 2003. Composition and antioxidant activity of the essential oil from Curcuma zedoaria. Food Chemistry, 82:583-591.

Mayor, L., and A.M. Sereno. 2004. Modelling shrinkage during convective drying of food materials: a review. Journal of Food Engineering 61:373-386.

Mohsenin, N.N. 1980. Thermal Properties of Foods and Agricultural Materials. Gordon and Breach Science Publishers, New York.

Phomkong, W.G., Srzednicki, and R.H. Driscoll. 2006. Thermophysical Properties of Stone Fruit. Drying Technology, 24: 195-200.

Rao, M.A., S.S.H. Rizvi, and A.K. Datta. 2005. Engineering Properties of Foods, $3^{\text {rd }} E d$. CRC Press, Singapore.

Rizvi, S.S.H. 2005. Thermodynamic properties of foods in dehydration. $\mathrm{Di}$ dalam: Rao MA, Rizvi SSH, Datta AK, (Eds). Engineering Properties of Foods. $3^{\text {rd }}$ Ed. CRC Press, Singapore. 
Seo, W.G., Hwang, J.C., Kang, S.K., Jin, U.H., Suh, S.J., Moon, S.K., Kim, C.H. 2005. Suppressive effect of Zedoariae rhizoma on pulmonary metastasis of B16 melanoma cells. Journal of Ethnopharmacology 101:249-257.

Singh, K.K., and T.K. Goswami. 2000. Thermal properties of cumin seed. Journal of Food Engineering 45: 181187.

Syukur, C. 2003. Temu Putih. Tanaman Obat Anti Kanker. Penebar Swadaya, Jakarta.
Weidenfellera, B., M. Hofer and F.R. Schilling. 2004. Thermal conductivity, thermal diffusivity, and specific heat capacity of particle filled polypropylene. Composites: PartA35 (2004): 423-429.

Wirakartakusumah, M.A., Kamaruddin A. dan A.M. Syarif. 1992. Sifat Fisik Pangan, Depdikbud, Dirjen Dikti, PAU Pangan dan Gizi, IPB-Bogor.

Yagua, C.V., and R.G. Moreira. 2011. Physical and thermal properties of potato chips during vacuum frying. Journal of Food Engineering 104: 272-283. 
